\title{
心理工学的アプローチによるアスリートの支援
}

\section{Athletes Support by the Pshycho-Engineering}

○武藤俊彦 関満彦 三宅仁

長岡技術科学大学

Toshihiko Muto Michihiko Seki Hitoshi Miyake

Nagaoka University of Technology

\section{1. 研究の背景・目的}

選手が何を考え、選手自身どんなふうに感じているか をコーチ及び指導者に伝える行為は、競技を続ける上で 選手誰もが日常的に経験することであり、選手が競技生 活とコーチ及び指導者の関係を築いていく上で欠かすこ とができないものである1）2）3。そこで、本研究の目的 は競泳選手のパフォーマンス向上のための情報共有シス テムを構筑することである。すなわち、全てのコーチ（指 導者）は選手の競技力の向上を望んでおり、パフォーマ ンス向上のためには情報の共有が必要とされている4）5？ これにより外見と内面のギャップが埋まり、コーチ・選 手間の情報共有が高まり、結果、競泳選手のパフォーマ ンスが向上すると思われる。しかし、なかなかリアルタ イムで選手の状況を正確に把握するのは困難である。そ こで、本研究の目的は心理工学的アプローチによる競泳 選手のパフォーマンス向上のための情報共有システムを 構築することにある。またその情報共有システムを用い てリアルタイムで情報を共有できる新たなメンタルサポ ートシステムを目指す。

\section{2. 研究方法}

被験者は新潟県国体競泳チームメンバーで中・高・D 般の競泳選手 26 名（男子 13 名、女子 13 名）を対象とし た。心理工学的アプローチとして、管理者が web 上にお いて選手から携带電話を用い、選手の自己開示を即し項 目用件（TSMI をべースに作成）よりデータ集約を行える システムを採用した。システム要件としてはコーチが全 選手のデータを閲覧でき、コーチは全選手のデータを更 新・書き込みすることができることとし、選手は自分の データをVASにて自由に書き込みすることができるこ ととした。またこの個々のデータをグラフ化し、よりビ ジュアル的にコーチが評価できる様に工夫した。そして そのデータから分析を試みた。

\section{1 システム要件定義}

(1) コーチ コーチは全選手のデータを閲覧できる。
コーチと選手の意見交換が可能に。

コーチは全選手のデータを更新することができる。

(2) 選手

自分のデータを自由に書き込みが可能。 他の選手のデータを閲覧禁止。

システムとしてはまず選手は自分の携帯電話で選手管 理 webにIDを用いてアクセスする。次に、そのサイトに 23 の項目にデー夕を書き込み、データを送信する。送 信されたデータは管理者が管理する管理者 web において 数值化される。また、データを書き込むだけでなく、自 分の泳ぎに関するコメントも記入してもらう。そしてデ 一夕は図 1 のシステムにおいて情報を共有する。また、 選手の書き込みと同様にコーチもその日のトレーニング メニュー、練習メニュー、コメント等を管理 web に書き 込みを行う。

\section{2 項目要件定義}

（1）競技意欲

忍耐力、䦔争心、自己実現意欲、勝利意欲 練習への意欲、向上心。

（2）精神の安定、集中

自己コントロール能力、リラックス能力、集 中力。

(3) コンディショニング

体調、疲労度、食欲、睡眠時間、練習の厳し さ。

（4）価值観、考え方

計画性、結果と努力の結びつけ、スキルなどに 関する関心、勝利へのこだわり、指導者への信 頼。

Fig. 1 のシステムはスター型。管理者が管理する web に収集した選手のデータを置き、いつでも不特定多数の コーチ等が閲覽できる。管理者がデータを一元的に管理 し、それを利用する 1 対 $\mathrm{n}$ 型のシステムである。 


\section{スター型}

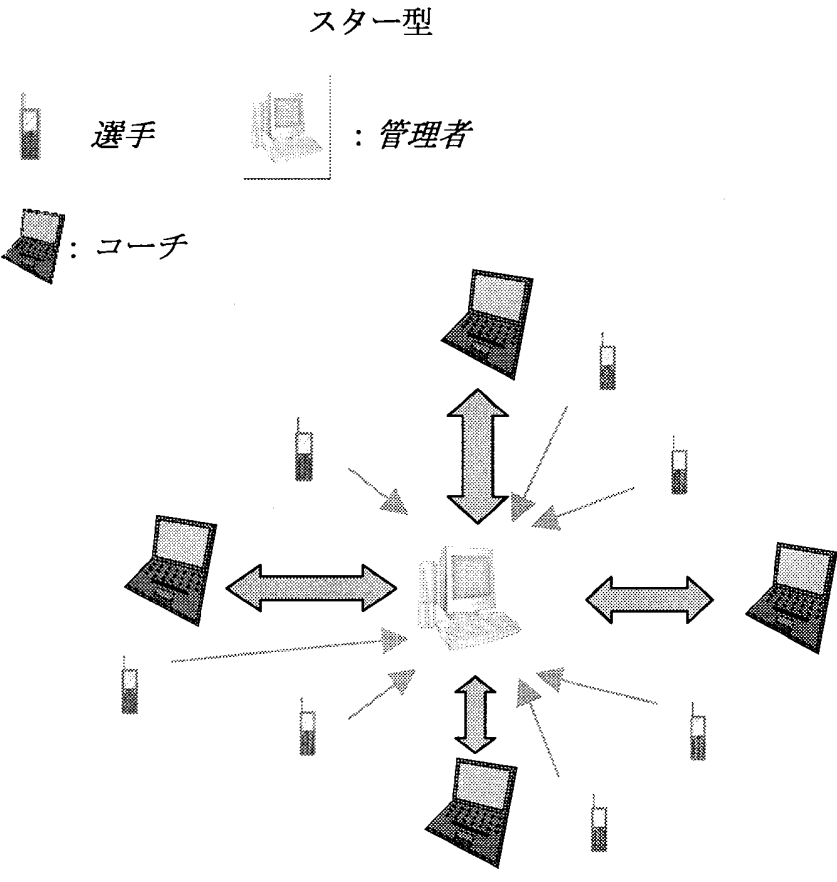

Fig. 1 Informational sharing system

\section{3. 結果}

今回、昨年 8 月中に行われた国体合宿と 9 月 9 日から の大分で開催された大分国体においてその期間データ収 集を行った。その後、1 2 月の際にもデ一タ収集を行っ た。データを取る際に携帯を媒体としたほうが、収集が よりスムーズに行われた。

結果の一例として fig.2 に示す。競泳選手の対人関係形 成や競技環境への適応など水泳選手の自己開示において、 心理状況やコンディショニングのフォローアップができ る方法論を示した。

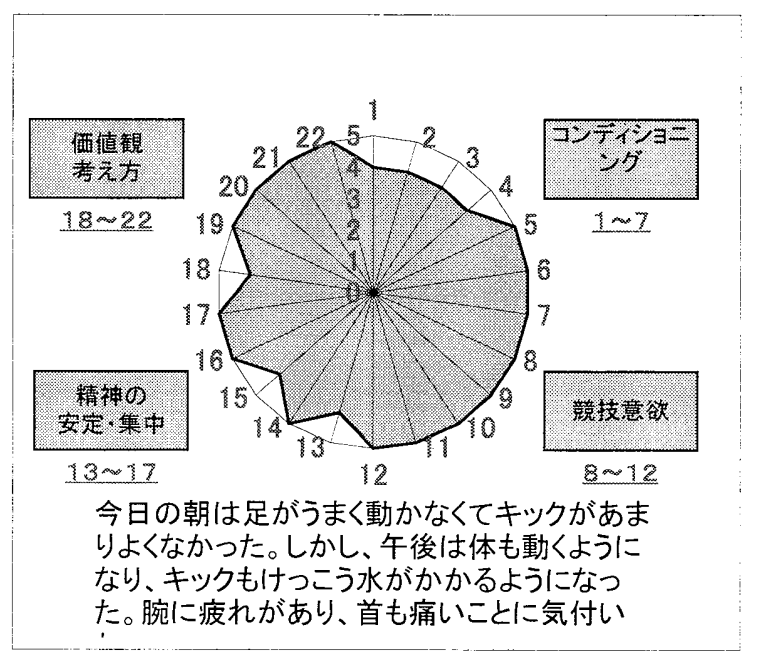

\section{4. 考察}

従来、このようなコーチング場面においては、対面指 導が主であったが、本研究では携带電話によるコミュニ ケーションツールを用いた。データを採取する際に、携 帯電話を媒体としたのは利便性を考慮してのことである。 当初、媒体をパソコンとしたデータの共有を試みたが、 選手が常にパソコンを持っていないこと、そして、パソ コンに不慣れな選手がいることから携帯電話を用いた。 システムとしては携帯電話の容量でも、データの共有の みなので間に合った。

\section{5. 結論 - 今後の課題}

今までコーチは選手の状態を判断する際、表面的な部 分で判断するしかなかった。しかし、心理工学的アプロ 一チを用いて精神的な部分を数值化することで選手の内 面をより詳しく察知することができ、選手に対するアプ ローチ方法を変化させることができる。また、的確なア プローチをすることによって、選手のパフォーマンス向 上につながっていくと思われる。

コーチの中には、使うのが面倒くさいという声が聞か れた。今後、システムを使う際にわずらわしさをなくす ことが課題に挙げられる。また今後、このシステムを用 いてさらにデータを収集し、競泳選手の心理的及びパフ オーマンス向上の研究を進めていく予定である。

\section{参考文献}

1)出口拓彦・吉田俊和: 対人社会心理学研究, 4, 51-56、 2004

2)榎本博明・清水弘司: 心理学研究，63，114-117 1992 3)榎本博明: 自己開示の心理学研究、北大路書房 1997 4)井上まや：関西大学大学院人間科学，65，207-219、 2006

5)丸山利弥・今川民雄: 対人社会心理学研究, 1, 107-118、 2001

6)内閣府：ITによる家族への影響実態調查 http://www5. cao. go. jp/seikatsu/2002/0405it-cho usa/index.html 2002

Fig. 2 player's date 